\title{
Küresel Isınmanın Türk Dış Politikasına Yansıması
}

\author{
Impacts of Global Warming on Turkish Foreign Policy
}

\author{
Nehir AĞIRSEVEn $^{1}$ (D), ARMAĞAn ÖrKi ${ }^{2}$
}

\section{Ö Z}

Bu makale, tamamlanıp yayımlanmamış bir doktora tezinden bu yayın için düzenlenmiştir. Doktora tezinde ilk bölüm olarak "Küresel Isınma Sorununa Genel Bakış” ve ikinci bölüm olaraksa "Küresel Isınma ile İlgili Uluslararası Politikalar” belirlenmiştir. $\mathrm{Bu}$ iki bölümden yararlanılarak hazırlanan bu makaledeyse ilk olarak küresel ısınma kavramına, çeşitli teorilerin iklim değişikliği yaklaşımlarına, küresel ısınmaya yol açan insani faaliyetlere ve küresel ısınmanın sosyo-ekonomik sonuçlarına yer verilmiştir. Sonraki bölümde, bu çevresel soruna ilişkin çok taraflı görüşmelere değinilmiş, başlıca sözleşme ve anlaşmalarla birlikte Türkiye’nin izlediği politikalara yer verilmiştir. Birleşmiş Milletler İklim Değişikliği Çerçeve Sözleşmesi, Kyoto Protokolü ve Paris İklim Anlaşması başta olmak üzere son otuz yılın en önemli girişimlerine görece ağırlık verilmiş ve Türkiye'nin iç politikasında da küresel ısınmaya karşı aldığı önlemler kronolojik olarak derlenmiştir.

Çalışma, doktora çalışmasında izlenen yol ve kullanılan kaynaklara sadık kalınarak dergi yayımı için sadeleştirilmiş ve çalışmaya Türk dış politikasına ilişkin konular eklenmiştir. Çalışmanın genelinde bilimsel makaleler, kitap ve kitap bölümleri ile haber sitelerinin, istatistik kurumlarının ve resmi makamların çevrimiçi sayfalarından yararlanılmıştır.

Anahtar Kelimeler: Küresel Isınma, Çevre Politikaları, Türk Dış Politikası.

\section{A B S T R A C T}

This article is composed for this edition of the journal from an unpublished doctoral dissertation. The two main chapters "An Overview on the Main Issues of Global Warming” and "International Policies Concerning Global Warming” were assigned in the doctoral dissertation. By drawing on these contents, the article first covers the concept of global warming, approaches of various theories to climate change, human activities that lead to global warming, and the socio-economic consequences of global warming. In the following part of the study, multilateral negotiations on this environmental problem were discussed, as well as the main contracts and agreements along with the policies followed by Turkey. Moreover, the United Nations Framework Convention on Climate Change, the Kyoto Protocol and the Paris Agreement, particularly focusing on the most important initiatives of the last thirty years, and measures against global warming in Turkey's domestic politics has been put together chronologically.

The study was simplified for the publication of the journal by adhering to the path followed and the resources used in the doctoral study, and the subjects concerning Turkish foreign policy were added to the study. Throughout the study, scientific articles, books and book chapters, and online resources of the institutions providing statistical data and other official authorities were utilized.

Keywords: Global Warming, Environmental Policies, Turkish Foreign Policy.

\section{DOI: $10.47934 /$ tife.010.01.01}

*Bu makale, Trakya Üniversitesi Sosyal Bilimler Enstitüsü Uluslararası İlişkiler Doktora Programı öğrencisi Nehir Ağırseven'in doktora tez çalışmasından düzenlenerek yayına hazırlanmıştır. 1983 Edirne doğumlu Nehir Ağırseven, doktora tez aşamasındayken, 21 Kasım 2019 tarihinde vefat etmiştir. Bu çalışma, genç akademisyenin harcadığı emeği ölümsüzleştirme ve yazına kazandırma amacıyla işbu yayın için düzenlenmiş halidir. Ayrıca doktora tez çalışmasının yayınlanabilmesi için metni gönderen, Nehir Ağırseven'in ablası Prof. Dr. Deniz Ağırseven'e de ayrıca teşekkürü bir borç bilirim.

1. Öğr. Gör., Trakya Üniversitesi, Yabancı Diller Bölümü, Edirne, Türkiye.

ORCID: 0000000220517790

2. Dr. Öğr. Üyesi, İstanbul Rumeli Üniversitesi, Uluslararası ilişkiler Bölümü, İstanbul, Türkiye. ORCID: 0000000269060031

SORUMlu Yazar / CoRresponding AUTHOR Armağan Orki,

İstanbul Rumeli Üniversitesi, İktisadi ve İdari Bilimler Fakültesi, İstanbul, Türkiye.

E-mail: a_orkiavsar@hotmail.com

$\begin{array}{ll}\text { BAŞUURU/SUBMITTED: } & 18.01 .2021 \\ \text { REVIZYON TALEBi / } & \\ \text { REVISION REQUESTED: } & 08.02 .2021 \\ \text { SON REVIZYON/ } & \\ \text { LAST REVISION : } & 23.02 .2021 \\ \text { KABUL/ACCEPTED: } & 03.03 .2021\end{array}$

Atıf / Citation: Ağırseven, N., Örki, A. (2021). Küresel ısınmanın Türk dış politikasına yansıması. Trakya Üniversitesi İktisadi ve İdari Bilimler Fakültesi e-Dergi, 10(1), 1-10, https://doi.org/10.47934/tife.10.01.01 


\section{Giriş}

Küresel ısınmanın Türk dış politikasına etkisinin bulunduğu varsayımıyla, çalışmada küresel ısınma ve çok taraflı görüşmelerle Türk dış politikasındaki ayrıntılar iki ayrı başlıkta ele alınmıştır. Küresel ısınma bölümünde öne çıkan iki uluslararası ilişkiler teorisinin konuya yaklaşımına, küresel ısınmaya neden olan insan faaliyetlerine ve sosyo-ekonomik sonuçlarına yer verilmiştir. Sonrasında ise çok taraflı görüşmeler Birleşmiş Milletler (BM) özelinde ele alınmış, devamında da Türkiye’nin aldığı başlıca karar ve uygulamalar dış politikasına paralel şekilde aktarılmıştır. Çalışmada doğruluğu sınanmak istenen hipotez, çevresel bir sorun olan küresel ısınmanın Türkiye özelinde dış politikada yer edinmiş olmasıdır. Öte yandan küresel ısınmanın dış politikadaki varlığının ağırlığı konusunda da bunun bir "yüksek politika" mı, "alçak politika" mı teşkil ettiği sorusunun yanıtlanması hedeflenmiştir.

Küresel ısınmaya neden olan insan faaliyetlerinde enerji talebinin önemli bir yeri bulunmaktadır. Enerji talebi her ne kadar genel bir çerçeve sunsa da, aslında kıt kaynakların kullanım şekli çevreye zarar vermektedir. Verilen zararın küresel ısınmaya olan etkisi ise sera gazı ${ }^{4}$ salınımıyla ilgilidir. Kömür, petrol ve benzer doğal kaynakların tüketim şekillerinden ötürü çevresel sorunlar ortaya çıkmaktadır. Dolayısıyla üretimde kullanılan bu kaynakların kullanım yöntemleri, çevre için bir tehdit oluşturmaktadır.

Uluslararası ilişkiler açısından bu konunun yansımalarından birisiyse, üretimin artırılıp dış ticaret fazlası verme amacının (ithalatın kısılıp ihracatın artırılması) devletlerarasında rekabete yol açması ve dolayısıyla çevre kaygısının ötelenmesi şeklinde olmaktadır. Gelişmiş ve gelişmekte olan ülkeler için petrol vazgeçilmez bir enerji kaynağı olup bu kaynağın da kıt olması ve talebinin artması maddi değerini artırmaktadır (Canbay, 2020: 470). Bir diğer seçenek olan yenilenebilir enerji kaynakları (rüzgâr, dalga vb.) ise maliyetleri ve sağladıkları verim nedeniyle fosil yakıtlara göre daha az tercih edilmektedir. Çevre kirliliğinin arttığı ve kıt kaynakların azaldığı koşullar altında sürdürülebilir kalkınma önemli bir çözüm seçeneği olarak ifade edilmektedir (Atabay ve Kaçmaz, 2007: 46). Her ne kadar çevresel kaygıların en aza indirilebilmesi için yenilenebilir enerji kaynakları daha doğru olsa da, fosil yakıtların kullanım oranı daha yüksektir. Zira fosil yakıtlara erişim ve onlardan enerji edinimi teknik nedenlerden ötürü daha kolaydır. Bu durumun ise iki sonucu vardır: Ya ucuz maliyet ve çevre kirliliği ya da yüksek maliyet ve temiz çevre. Devletlerarası rekabet düşünüldüğünde çevre politikalarına ne kadar önem verilebileceği ise bir bilinmezlik olarak durmaktadır.

\section{Küresel Isınma}

İnsanla doğa arasındaki dengenin bozulmasındaki birincil neden, 19'uncu yüzyılda başlayıp gelişen sanayileşme sürecidir (ilker ve Alkin, 1991: 1). Bunun da kökenine gidildiğinde sırasıyla Kavimler Göçü, derebeylik rejiminin ortaya çıkışı, Haçlı Seferleri, coğrafi keşifler ve ardından Sanayi Devrimi gösterilebilmektedir. Yüzyıllarca süren sosyal, ekonomik, askerî ve siyasal gelişmelerin sonucunda kentleşmenin artması, nüfusun belli yerlerde yoğunlaşmasına ve kontrolsüzce üretime geçilmesine neden olmuş ya da en azından bu duruma zemin hazırlamıştır. Ardından ise 19'uncu yüzyılda insanlığın doğaya verdiği zarar somut bir hâl almıştır.

Bu bölümde öncelikle realizm ile liberalizmin iklim değişikliğine olan yaklaşımına yer verilmiştir. Sonrasında ise küresel ısınmaya neden olan insanlığın faaliyetlerine değinilmiştir. Takip eden aşamada küresel ısınmanın sosyo-ekonomik etkilerine odaklanılmıştır.

\footnotetext{
${ }^{4}$ Kloroflorokarbonlar, karbondioksit, metan, diazot monoksit gibi gazların geneline verilen ortak isimdir (Özmen, 2009: 43). 


\subsection{Başlıca İki Teorinin (Realizm ve Liberalizm) İklim Değişikliğine Yaklaşımı ${ }^{5}$}

Günümüzde iklim değişikliği küresel diplomaside oldukça önemli bir rol oynadığı gibi, en karmaşık küresel politika sorunlarından biri haline gelmiştir. Bu karmaşık sorunun yaratıcıları, zengin sanayileşmiş ülkeler olup küresel ısınmanın nispeten daha az mağdur olan tarafıyken, en fazla etkilenen taraf ise soruna en az katkısı olan yoksul ülkelerdir. İklim değişikliği hem sebep hem de etkileri bakımından küresel olup ortak eylem sorunu olarak yine uluslararası işbirliğine dayanan bir çözüm gerektirmektedir. En azından idealist yaklaşım bu işbirliğine işaret etmektedir. Uluslararası ilişkilerde devletler bir durum ya da olay karşısında işbirliği, tek taraflılık ya da eylemsizlik gibi üç farklı yaklaşım sergileyebilmektedir. iklim diplomasisi alanında ise devletlerin bu rollerin hepsini oynadığı söylenebilir. Teorik yaklaşımlar tüm devletler için bir tehdit oluşturan küresel ısınma sorununu farklı şekillerde ele almaktadır (Khan, 2016: 1415).

Uluslararası ilişkiler teorileri içinde klasik ve çağdaş olanların tümünde çevre ve çevre sorunlarına ilişkin yaklaşımlar bulunmaktadır. Yeşil teori başta olmak üzere teorilerin genelinde bu konuya dönük varsayım ve savlar oluşturulmuştur. Öte yandan uluslararası ilişkiler literatüründe en yoğun bulunan ve sıklıkla başvurulan iki teori ise realizm ile liberalizmdir.

Realizmde doğa ancak, güç, güvenlik ve ulusal çıkarlar söz konusu olduğunda kullanılacak bir araç niteliğindedir. Realist bakış açısına göre, çevre tahribatı, nüfus artışı, kaynak paylaşımı ve kıtlık gibi konular, devletler arasında gerginlik ve çatışmalara yol açtığı için çevre konusu güvenlik politikaları kapsamında değerlendirilmektedir (Söker ve Özlük, 2018: 230). Realistler egemen devletleri, devletler arasındaki ilişkileri yönetecek üst otoritenin bulunmadığı anarşik uluslararası sistemde temel aktör olarak görmüştür (Habib, 2011: 8). Devletler arasında savaşlara neden olabilecek çevre sorunu yine sadece devletler tarafından ele alınmaktadır. Çevrenin devlet açısından önemi, sağladığı faydayla ilgilidir. Eğer çevresel sorunlar devlet çıkarlarına zarar veriyorsa (enerjide bağımlılık, turizm sektörünün zayıflaması, gıda sorunu gibi) devletin yasama ve yürütme ajandasına girebilir. Aksi takdirde tali (alçak politika) seviyede kalacaktır.

Liberalizme göre doğa, insanların ihtiyaçlarını gideren bir kaynaktır. Çevresel sorunların, insanların sağlık ve refahı, çatışmanın önlenerek uluslararası barışın sağlanması için çözümlenmesi şarttır. Realizm gibi çevre sorunlarında devlete uluslararası sistem içinde merkezi bir rol yüklese de, liberalizm konuya sadece güvenlik açısından bakmamakta, çok taraflı anlaşmalar ve kurumsal yapılar aracılığıyla çözüme ulaşılabileceğini savunmaktadır. Bu yaklaşıma göre, devletler ortak irade oluşturup ortak eylem, anlaşma ve politikalara eşit seviyede katılırlarsa çevre sorunları çözülebilir. Karbon salınımına sınır getiren anlaşmalar gibi uluslararası anlaşmalara katılımın getireceği mali yükümlülükler kolektif eylem sorununa neden olabilmektedir. Sınırlama ve maliyetin adaletli bir şekilde paylaşımı ya da ülkelerin ekonomik güçleriyle doğru orantılı bir dağılım bu sorunun çözümünü de getirebilir. Liberal kurumsalcı yaklaşım, çevre sorunlarının çözüm sürecinde devleti temel aktör olarak kabul etmekle birlikte sivil toplum kuruluşları ve uluslararası örgütleri de kamuoyunda çevre sorunları farkındalığı oluşturmaları bakımından baskı unsuru olarak görmektedir.

\subsection{Küresel Isınmaya İnsanlığın Etkisi}

Küresel ısınmaya yol açan nedenler ikiye ayrılmaktadır: Birincisi, doğal nedenlerdir. íkincisi ise insanlığın faaliyetlerinden kaynaklanmaktadır. Bunları insan ve doğa ilişkisi, sera gazı salınımı, sanayileşme, nüfus artışı, kentleşme, ormansızlaştırma olarak sıralamak mümkündür.

\footnotetext{
${ }^{5}$ Doktora çalışmasında ele alınan tüm teorilere yer verilmemiş ve işbu çalışmada iki tanesine kısaca değinilmiştir.
} 
Çevre sorunlarına yol açan en önemli etkenlerden biri doğayı tamamen insanın yönetimine terk eden, insanı doğanın efendisi kabul eden ekolojik dengeden yoksun görüştür. Bu görüş, bilinçsizce davranılmasına olanak tanımaktadır. Bir diğer ifadeyle, insanlığın kısa vadeli kendi çıkarlarına dönük olarak doğayı ve yerküredeki dengeyi dikkate almadan eyleme geçmesine neden olmaktadır. Bu sorunun çözümüne ilişkin tek güvenilir yöntem ise küçük yaşta başlayan eğitimle bilinçlendirmedir. Öte yandan bu durumun mutlak bir somut sonuca ulaşabilmesi için küresel çapta ele alınması gerektiği düşünülmektedir.

Sanayi Devriminden sonra insan kaynaklı sera gazlarının artması sonucu dengenin bozulması ile yerkürenin yüzey sıcaklığında değişimler meydana gelmeye başlamıştır (Başoğlu, 2014: 20-21). Sera gazları doğada bulunduğu gibi, insan faaliyetleri sonucu da ortaya çıkmaktadır. Asıl sorun ise, doğada bulunan sera gazları değil, insan faaliyetleriyle sera gazı oranının normalin üstüne çıkmasıyla oluşmaktadır. Üretim ve tüketimdeki aşırılık ile mutlak surette en yüksek kârlııı arayışı, sanayileşmiş ülkelerin henüz kabullenmediği bir gerçekliktir (Atabay ve Kaçmaz, 2007: 49). Bu noktada kalkınma sürecinde olan devletlerin ekonomik ve benzer alanlardaki düzenlemeleri hayata geçirmesi ve böylelikle üretimi artırıp sosyal ve ekonomik yapıyı değiştirmesi normal bir durumdur (Çiloğlu, 2018: 46). Durumun zararlı tarafıysa, sürdürülebilir çevrenin göz ardı edilip kısa vadeli kalkınma arayışlarının varlığıdır.

Sera gazları, teknolojinin hızla gelişmekte olduğu modern hayatın sürdürülebilmesi için gereken üretim işlemlerinin bir sonucu olarak da ortaya çıkmaktadır. Bu da hem üretim teknolojilerine hem sanayileşmeye ve dolaylı da olsa küreselleşmeye bağlı bir sonuçtur. Sanayi devrimini takip eden nüfus artışı durumu daha da kötüleştirmiştir. Daha fazla tarım alanı ve kentsel alanlara intiyaç duyulmuş, bu da ormansızlaştırma ve çevrenin değişmesine yol açmıştır. 1975-1996 yılları arasında 93 ülkeyi kapsayan bir çalışmada, gelişmekte olan ülkelerde nüfus artışının gelişmiş ülkelere nazaran karbondioksit emisyonunu daha fazla etkilediğini ortaya koymuştur (Yılmazer ve Çınar, 2017: 42-43). Ormansızlaşmayla ilgili olarak erozyonu ve selleri artırdığı, su kaynaklarını azalttığı, iklimi değiştirebildiği de paylaşılmıştır (illker ve Alkin, 1991: 8).

\subsection{Küresel Isınmanın Sosyo-Ekonomik Etkileri}

Küresel ısınmanın etkilerini birden fazla sınıfa bölerek incelemek mümkündür. Öte yandan işbu yayın için sadece sosyo-ekonomik etkilerine kısaca değinilmesi uygun bulunmuştur. Buzulların erimesi, su kaynaklarının daralması, ani su baskını ve sellerin oluşması, fırtınaların artması, vahşi hayat ve biyolojik çeşitlilik üstündeki etkileri gibi görece doğal ya da tali sayılabilecek sonuçlar bile insanlık için bir risk olarak görünmektedir. Sadece bu etkiler bile sosyo-ekonomik yaşamda sonuç doğurabilir.

Küresel ısınma ile ilgili kaygı uyandıran en önemli konulardan biri tarım üzerinde gerek bölgesel gerekse küresel düzeyde yaratacağı etki ve dünyanın kendini besleyip besleyemeyeceği sorusudur (Maslin, 2011: 133-134). İklim değişikliği hayvancılık faaliyetleri için de yem bitkilerinin niteliği, su kaynakları, hayvan ve süt ürünleri, hayvan sağlığı, üreme ve biyolojik çeşitlilik açısından tehdit oluşturmaktadır (RojasDowning, Nejadhashemi, Harrigan ve Woznicki, 2017: 145). Genel olarak ziraat konusundaki bu etkileri, iç ve dış göçlere, işsizliğe, gıda güvenliğinin riske girmesine, azalan üretimden dolayı enflasyona neden olabilmektedir. Realist açıdan devlet çıkarı düşünüldüğünde, ekonomik birer kayba neden olduğunun da altı çizilmelidir.

Birçok devlet için önemli bir gelir kaynağı olan turizm de çevre kirliliğinden etkilenebilecek bir sektör olup turizm merkezlerinin en önemli odak noktası da doğa olarak gösterilmiştir (Örki ve Ağırseven, 2016: 98-99). Ülkelerin bulundukları coğrafyalara göre iklim değişikliğinden farklı kapsamlarda etkilenebileceği bilinmektedir. Türkiye özelinde düşünüldüğünde deniz turizminin canlı olduğu bölgelerde orman yangınlarının artması sonucu cazibenin yitirilmesi ve kış turizminin yapıldığı yerlerde karlılık süresinin azalması gibi düşünülebilir (Yıldız, 2009: 83-84). 
İklim değişikliği nedeniyle buhar ve soğutma işlevini yerine getirmek için suya ihtiyaç duyan termik ve nükleer elektrik santralleri, özellikle de su kaynaklarına duyarlı hidroelektrik santrallerinin etkin kullanımı aksayabilmektedir (Alper ve Anbar, 2007: 16). Değişen iklim ve aşırı hava olayları güneş ve rüzgâr enerjisi üretimi üzerinde de etkili olmaktadır.

Aşırı sıcaklardan, kuvvetli fırtınalara kadar birçok iklim olayı insan sağlığı üzerinde etkili olabilmektedir. Kuraklık sonucu su kaynaklarında meydana gelen azalma ve kıyı ekosistemlerinin zarar görmesi ile kolera, dizanteri ve tifo gibi bulaşıcı hastalıkların ortaya çıkması iklim değişikliğinin neden olduğu diğer dolaylı etkilerdendir (Polat, Eren ve Aydın, 2017: 155-156).

Çevre kirliliği ve küresel ısınmanın devletler özelinde dolaylı ekonomik sonuçları da bulunmaktadır. Örneğin, kentleşmeyle daha yoğun bir sorun hâlini alan katı atıklar, ekonomik sonuçlara da sahiptir. Katı atıkların doğru şekilde bertaraf edilememesinin çeşitli hastalıklara yol açtığı, su ve hava kirliliğine neden olduğu, kanalizasyon sistemlerinin tıkanması gibi ekonomik sonuçları bulunduğu aktarılmıştır (Tekel, 2007: 275). Buna karşın katı atıklardan deniz dolguları yapılması veya elektrik üretilmesi gibi ekonomik ve çevreci çözümler bulunmaktadır.

İklim değişikliği dünyanın bazı yerlerini daha az yaşanabilir hale getirerek, gıda ve su kaynaklarını etkileyerek, sel ve fırtınaların sıklığını ve şiddetini arttırarak nüfus hareketlerine neden olmaktadır. İklim değişikliğinin etkisiyle yaşanan doğal afetler, güvenlikle ilgili ve ekonomik kaygılarla da birleşince, binlerce yıldır kaynaklara rahat erişebildiği elverişli doğa koşullarında varlığını sürdürmeyi arzu eden insanı çevre değiştirmeye yönlendirmektedir. Göç akınları, küresel ısınmanın dünya üzerinde yarattığı tehditlerden biri olarak ülkeler arasında sınır sorunu gibi anlaşmazlıklara neden olabileceğinden, ülkeler gerekli tedbirleri almalıdır.

Kısacası, küresel ısınmanın sosyo-ekonomik sonuçları doğanın tahrip olması kaynaklıdır. Ayrıca doğrudan veya dolaylı olarak siyasal, sosyal, ekonomik sonuçları vardır ve bu sonuçların da arasında bir bağ mevcuttur.

\section{Küresel Isınmaya ilişkin Çok Taraflı Görüşmeler ve Türk Dış Politikası ile Uygulamalar}

Çevre sorunlarıyla ilgili hükûmetlerarası çok taraflı görüşmelerin yapılması, özellikle çevre konusunun dış politika alanında daha yoğun olarak gündeme geldiği dönemlere rastlamaktadır. Bu işbirliği arayışlarının ilki 1972' de İsveç'te yapılan BM İnsan Çevresi Konferansı olmuş ve kısa süre sonrasında 1973 Petrol Krizi ile beraber tekrar gündeme gelmiştir. 1972 sonrasında sanayileşmiş ülkelerde çeşitli örgütler kurulmuş, yeni politikalar geliştirilmiş; ancak somut bir ilerleme sağlanamamıştır (Atabay ve Kaçmaz, 2007: 41). 1970 'li ve $80^{\prime}$ li yıllarda çeşitli çalışmalar yapılmaya devam edilmiş; ancak en önemlisi 1992'de yapılan ve 1994'te yürürlüğe giren BM İklim Değişikliği Çerçeve Sözleşmesi olmuştur. 1994 yılından itibaren gerçekleştirilen Taraflar Konferansı'nın üçüncüsü 1997'de Kyoto'da gerçekleştirilmiş ve burada sera gazı salınımının düşürülmesine dönük hedefleri içeren Kyoto Protokolü imzalanmıştır (Sadioğlu ve Ağıralan, 2020: 363).

1957 yılında kurulan Avrupa Ekonomik Topluluğunun (AET) çevre politikaları da 1970'li yıllara kadar ciddi bir önem barındırmamış; ancak 1972'deki BM şemsiyesi altındaki zirveyle ilk adım atılabilmiştir (Erdem ve Yenilmez, 2017: 95-96). NATO, OECD, UNEP, UNIDO gibi kuruluşlar saptama, önleme ve giderme gibi projeler üstünde durmakta, çevre kirliliğini azaltma konusunda odaklanmaktadır (illker ve Alkin, 1991: 11-14).

\subsection{Birleşmiş Milletler İklim Değişikliği Çerçeve Sözleşmesi}


İklim değişikliğini ele alacak hukuki süreç, yeni bir anlaşma için müzakere yapılmasını gerektirmekteydi. Başlangıçta iki alternatif model düşünülmüştür. Birincisi, 1982 BM Deniz Hukuku Sözleşmesi'ni örnek alan ve atmosfer sorunlarının karşılıklı bağımlılığını tanıyacak ve sorunlara kapsamlı bir yaklaşım sunacak atmosfer hukuku üzerine genel çerçeve anlaşması; ikincisi ise ozon tabakasının korunmasına dair Viyana Sözleşmesi'ni model alan iklim değişikliği sözleşmesi olmuştur. İkinci alternatif üstün gelmiş ve resmi sözleşme hazırlama süreci Aralık 1990'da BM Genel Kurulu'nun, İklim Değişikliği Çerçeve Sözleşmesi için Hükümetler arası Müzakere Komitesi'ni oluşturmasıyla başlamıştır. Iklim Değişikliği Çerçeve Sözleşmesi hükümleri bütün tarafların konumlarını koruyarak aslında birçok konuyu çözmek yerine ötelemiş, devam eden müzakere sürecine bir virgül koymuştur. 1992'de imzaya açılan sözleşme, iki yıl sonra yürürlüğe girmiştir.

\subsection{Kyoto Protokolü ve Birinci Yükümlülük Dönemi}

Kyoto Protokolü, BM İklim Değişikliği Çerçeve Sözleşmesi kapsamında belirlenen hedeflerine giden yolda ilk önemli somut adım olarak değerlendirilmektedir. Protokol, Japonya'nın Kyoto kentinde 1997 yılında düzenlenen Üçüncü Taraflar Konferansı'nda imzaya açılmış, 16 Şubat 2005'te resmen yürürlüğe girmiştir (Talu, 2015: 204). Kyoto Protokolü, küresel iklim sorununa çare bulmada ne başlangıçta ne de daha sonra tam anlamıyla başarılı olmuştur. Kyoto Protokolü'nde devletler iki ana gruba ayrılmıştır ve bu ayrım T. C. Dışişleri Bakanlığı (2020) tarafından şöyle açıklanmaktadır:

“Ek-ı Ülkeleri: (...) sera gazı emisyonlarını sınırlandırmak, sera gazı yutaklarını korumak ve geliştirmek, ayrıca, iklim değişikliğini önlemek için aldıkları önlemleri ve izledikleri politikaları bildirmek ve mevcut sera gazı emisyonlarını ve emisyonlarla ilgili verileri iletmekle yükümlüdürler. Bu grup iki ülke kümesinden oluşmaktadır. Birinci grupta 1992 yılı itibarıyla OECD üyesi olan ülkeler (bunların içinde Türkiye de vardır) ve $A B$, ikinci grupta ise Pazar Ekonomisine geçiş sürecindeki ülkeler yer almaktadır.

Ek-Il Ülkeleri: (...) birinci grupta üstlendikleri yükümlülüklere ilaveten çevreye uyumlu teknolojilerin özellikle gelişme yolundaki taraf ülkelere aktarılması veya bu teknolojilere erişimin teşvik edilmesi, kolaylaştırılması ve finanse edilmesi hususlarında her türlü adımı atmakla sorumlu kılınmışlardır.

Ek Dışı Ülkeler: (...) sera gazı emisyonlarını azaltmaya, araştırma ve teknoloji transferine ilişkin işbirliği yapmaya ve sera gazı yutaklarını korumaya teşvik edilmekte, ancak belirli bir yükümlülük altına alınmamaktadırlar."

\subsubsection{Yılına Kadar Görüşmeler ve Paris İklim Anlaşması}

1995 yılında Berlin'de başlayarak 2020'ye dek aralıksız çok taraflı görüşmeler sürdürülmüştür. 2020 'de ise görüşmeler yapılamamıştır. 2021'de Glasgow'da 28ncisinin düzenlenmesi planlanmaktadır.

2012'de Doha'da yapılan görüşmede sadece gelişmiş ülkelerin değil, tüm ülkelerin sorumluk üstlenmelerine karar verilmiştir (Talu, 2015: 240-242). Doha'da yapılan görüşme dışında en çok ses getirmeyi başaran etkinlikse 2015 'te düzenlenmiş olandır.

Paris Anlaşması, 12 Aralık 2015 tarihinde Paris'te düzenlenen 21. Taraflar Konferansı'nda 195 ülkenin onayıyla kabul edilen ilk uluslararası ve yasal bağlayıcılığa sahip iklim anlaşmasıdır (European Commission, 2018). ABD, söz konusu anlaşmadan ayrılmıştır. Akaryakıta yapılan zamlar dolayısıyla Fransa'da da toplumsal olaylar (sarı yelekliler) yaşanmış ve Fransa'nın da ilgili anlaşmayı işlevsel şekilde sürdüremediği ortaya çıkmıştır. Biri küresel, diğeri bölgesel iki gücün "bağlayıcılığı olan" bir anlaşma 
karşısındaki tutumları değerlendirildiğinde, Kyoto Protokolü gibi etkisinin bulunmadığı ya da çok az bulunduğu düşünülmektedir.

\subsection{Türkiye'nin Küresel Isınmaya Iliş̧kin Başlıca Karar ve Uygulamaları}

1960’lı yıllara kadar Türkiye'de çevre konusunda önemli bir girişim olmamıştır; çünkü bu sürece kadar sanayileşme düzeyi de çevre için ciddi bir risk oluşturmamış ve sanayileşme hızıyla birlikte zaman içinde çevre konusu uluslararası anlaşmalar dikkate alınarak hayata geçirilmiştir (Erdem ve Yenilmez, 2017: 103). Pek gerçekçi kabul edilmeyen üretim ve tüketim faaliyetlerinin düşürülmesi, maliyeti yüksek olabilecek yeni teknolojilerden faydalanılması ve baştan önleyici (yer seçimi, teknik belirlenmesi vb.) uygulamalar çevre sorunlarına ilişkin birer çözüm olarak sunulmuştur (ilker ve Alkin, 1991: 29).

Çevre politikalarında enerji talebinin ve kaynaklarının da önemi olduğu düşünülebilir. Konuyla ilgili Bakanlık, 2019 Faaliyet Raporu'nda hem enerji hammadde ve teknolojilerinde dışa bağımlı olunmasını hem de birincil enerji kaynakları oranının düşük olmasını zayıfıklar listesinde anmıştır (T. C. Enerji ve Tabii Kaynaklar Bakanlığı, 2020a: 159).

1970'li yıllarda Türkiye'de uygulanan çevre politikalarının AET kararlarıyla uyumlu olduğu tespit edilmiştir (Erdem ve Yenilmez, 2017: 104). Katı atık konusunda kendi politikalarını uygulayan Türkiye, 2004 yılında $A B^{\prime}$ ye uyum çerçevesinde katı atık politikalarını $A B$ ile uyumlu hâle getirme konusunda ilk ciddi ve somut adımı atmıştır (Tekel, 2007: 283).

Kyoto Protokolü'nün hem Ek-I hem de Ek-II listesinde yer alan Türkiye, kendi isteğiyle Ek-II'den çıkartılıp 2004'te resmen sözleşmeye taraf olmuş, 2009' da ise Resmi Gazete' de yayınlanmıştır (T. C. Enerji ve Tabii Kaynaklar Bakanlığı, 2020b). Katılım ve onay tarihlerinden ötürü, 2020 yılına kadarki sorumluluk durumu Türkiye için söz konusu olmamış; ancak 2016'da Paris İklim Anlaşması imzalanıp yürürlüğe girmiştir (T. C. Enerji ve Tabii Kaynaklar Bakanlığı, 2020b).

Çevre kirliliğiyle ilgili vergi, firmalar için kirlilik miktar kısıtlaması, sübvansiyonla arıtım tesislerinin teşviki gibi yöntemler de birer seçenektir (ilker ve Alkin, 1991: 33). Ayrıca belediyeler ve şirketler tarafından çeşitli yöntemlerle enerji üretimi yapılabilmektedir. Bu yöntemler incelendiğinde, hem enerjide dışa bağımlılığı azaltma konusunda hem de çevre kirliliğini önleme adına önem barındırdıkları söylenebilir.

2009'la 2019 yılları arasındaki birincil enerji kaynaklarına göre Türkiye'deki kurulu güçte en büyük yenilik Güneş enerjisinde yaşanmıştır. 2009'da Güneş enerjisi bulunmuyorken, 2019'da ortalama \%6.5 seviyesine ulaşılmıştır (TEIAŞ, 2020a). Rüzgârdaki oran ise \%1.75 seviyesinden \%8'in üstüne çıkmıştır (TEIAŞ, 2020a). 2019 yılındaki yenilenebilir enerji üretiminde ise bu yolla gerçekleşen üretiminin yaklaşık çeyreği sadece Güneş ve rüzgâr enerjisinden yararlanılarak üretilmiştir (TEIAŞ, 2020b). Toplam üretimdeyse ikisinin toplamı \%10 seviyesinde kalmıştır (TEIAŞ, 2020c).

Ülkelerde Yıldırım'ın (2019: 333) aktardı̆̆ı “düzenleyici politikalar, mali teşvikler, kamu yatırımları, krediler ve hibeler, destekleme mekanizmaları, lisanssız üretim hakkı (...) düzenleyici politikalar, mali teşvikler, kamu yatırımları..." gibi politikalar uygulanabilmektedir. Yenilenebilir enerji kaynaklarının artırılması için de gümrük vergisi muafiyeti ve katma değer vergisi istisnası gibi özendirici politikalar uygulanabilmektedir. Vurgulanması gereken bir nokta da, bu politikaların hem enerjide dışa bağımlılı̆ın azalması hem de çevre sorunlarının en aza indirilmesi için önemli olmasıdır.

Uluslararası Çevre Eğitim Vakfı'nın hayata geçirdiği Mavi Bayrak uygulaması Türkiye'de de yürürlükte olup 2020 yılında 500'e yakın plaj, 20'yi geçkin marina ve 7 tane yata bu bayrak verilmiştir (TÜRÇEV, 2020). Çevreye Duyarlı Konaklama Tesisi (Yeşil Yıldız Simgesi) Belgesi de yine turizmle ilgili bir teşvik politikasıdır. Yeşil Yıldız Simgesi alan konaklama tesisleri enerji konusunda destek almış ve böylelikle 
çevre duyarlılığı teşvik edilmiştir. Bu ve benzer uygulamalar doğrudan çevreye veya turizme dönük yorumlanmayabilir; ancak şirketler temelinde teşvik edici, özendirici ve çevresel kaygılara yanıt verebilecek özelliktedir.

\section{Sonuç Yerine}

Küresel ısınma, özellikle insanlık faaliyetlerinden ötürü sürdürülebilir çevreyi tehdit etmektedir. Çevrenin bozulması ise insan sağlığından gıda güvenliğine, turizmden doğal afetlerin daha sık ve şiddetli yaşanmasına kadar bir dizi sonuca neden olmaktadır. Sonuçları itibariyle çevre sorunlarının ve daha özelde küresel ısınmanın devletler için de ekonomik sonuçları olmaktadır. Örneğin insan sağlığına olan etkileri düşünüldüğünde, bu yöndeki harcamaların artacağı veya tarıma olan etkileri düşünüldüğünde, gıda ve tarım talebini karşılayamama durumu devletler için önem barındıran sonuçlar olarak belirmektedir.

Türkiye'de çevresel kaygılara dönük uygulamalar incelendiğinde uluslararası bir anlaşmaya bağlılıktan öte, kendi iç aktörlerinin beklentilerini karşılama ve sürdürülebilir çevre amacıyla yaşama dâhil edildiği görülebilmektedir. Bununla birlikte farklı uygulamalardan yararlanıldığı, bunların örnek alınıp uyarlandığı da anlaşılmaktadır. Bir diğer vurgulanması gereken konu ise, uygulamaların tümüyle çevresel kaygılardan kaynaklanmadığı, ayrıca yenilenebilir enerji konusundaki politikalarda, enerjide dışa bağımlılığın azaltılmasının da hedeflendiği görülmektedir. Dolayısıyla enerji politikalarıyla çevre politikalarının küresel ısınma özelinde etkileri olduğu anlaşılmaktadır. Devletlerin yenilenebilir enerji kaynaklarına dönük politikaları, hem ekonomileri hem de sürdürülebilir çevre için önemlidir. Devletlerin motivasyon kaynağı ekonomilerini güçlü tutup savunma harcamalarını artırabilmek bile olsa, izlenen çevreci politikalar yerküre için değerlidir.

Türk dış politikasında küresel ısınmanın önemli bir ayrıntı olmadığı, hatta uluslararası ilişkiler terimlerinden alçak ve yüksek politika kavramlarına istinaden çevre politikalarının içinde yer aldığı alçak politikaların arasında yer aldığı söylenebilir. Bununla birlikte enerji politikalarının yeri, görece daha yüksek seviyedir. Çevre ve enerji konuları doğrudan ekonomiyle ve dolaylı olarak ulusal güvenlikle bağlantılıdır. Dolayısıyla enerji politikalarında yer edinen yenilenebilir enerji politikaları, hem çevre hem enerji hem de ekonomi için değerlidir.

\footnotetext{
Hakem Değerlendirmesi: Dış bağımsız.

Çıkar Çatışması: Yazar çıkar çatışması bildirmemiştir.

Finansal Destek: Yazar bu çalışma için finansal destek almadığını beyan etmiştir.
}

\section{KAYNAKÇA}

Alper, D., Anbar, A. (2007). Küresel ısınmanın Dünya ekonomisine ve Türkiye ekonomisine etkileri, Dokuz Eylül Üniversitesi Sosyal Bilimler Enstitüsü Dergisi, 9(4): 15-54.

Atabey, S., Kaçmaz, G. (2007). Çevre duyarlılığının piyasa ekonomisine yenik düştüğü nokta: Sürdürülebilir kalkınma, A. Mengi (Ed.) Çevre ve politika: Başka bir Dünya özlemi, (s. 41-51) içinde. Ankara.

Başoğlu, A. (2014). Küresel iklim değişikliğinin ekonomik etkileri üzerine model denemesi ve ekonometrik bir analiz, (Yayımlanmamış Doktora Tezi). Karadeniz Teknik Üniversitesi, Sosyal Bilimler Enstitüsü, Iiktisat Anabilim Dalı, Trabzon. 
Canbay, Ş. (2020). Türkiye'de elektrik üretimi için kullanılan petrol tüketimi, yenilenebilir enerji kullanımı ile iktisadi büyüme arasındaki ilişkilerin analizi, EKEV Akademi Dergisi, Sayı: 81, 467-488.

Çiloğlu, T (2018). Yeşil ekonomi ve küreselleşme: Karşılıklı etkileşim ve dönüşümsel süreç, İmir Kâtip Çelebi Üniversitesi iiBF Dergisi, 1(1): 42-48.

Erdem, M. S., Yenilmez, F. (2017). Türkiye'nin Avrupa Birliği çevre politikalarına uyum sürecinin değerlendirilmesi, Optimum Ekonomi ve Yönetim Bilimleri Dergisi, 4(2): 91-119.

European Commission, Paris Agreement, https://ec.europa.eu/clima/policies/international/negotiations/paris_en, (04.10.2018)

Habib, B. (2011). Climate change and international relations theory: Northeast Asia as a case study", Proceedings of the Third Global International Studies Conference, 1-31.

İlker, A., Alkin, E. (1991). Çevre Sorunları, TOBB.

Khan, M. R. (2016). Climate change, adaptation and international relations theory, G. Sosa-Nunez, E. Atkins (Ed.) Environment, climate change and international relations (s. 14-28) içinde. İngiltere.

Maslin, M. (2011). Küresel ısınma, Ankara.

Örki, A. Ağırseven, N. (2016). Sustainable environment in tourism policies: The case of Turkey, Uluslararası Türk Dünyası Turizm Araştırmaları Dergisi, 1(2): 97-106.

Özmen, M. T. (2009). Sera gazı - Küresel ısınma ve Kyoto Protokolü, Türkiye Mühendislik Haberleri, Sayı: $453,42-46$.

Polat, E., Eren, M. V., Aydın, H. İ. (2017). Sürdürülebilir kalkınmada iklim değişikliğinin sağlık üzerindeki etkisinin ampirik analizi, H. Atik (Ed.) Küresel ısınma, iklim değişikliği ve sosyo-ekonomik etkileri, (s. 149-168) içinde. Ankara.

Rojas-Downing, M. M., Nejadhashemi, A. P., Harrigan, T., Woznicki, S. A. (2017). Climate change and livestock: Impacts, adaptation, and mitigation, Climate Risk Management, Sayı: 16, 145-163.

Sadioğlu, U., Ağıralan, E. (2020). İklim değişikliği çerçevesinde 25. taraflar konferansı (COP 25), KAÜiiBFD, 11(Ek Sayı 1): 361-385.

Söker, Ç., Özlük, E. (2018). Uluslararası ilişkilerde çevreyi merkeze taşımak: Temel yaklaşımlar ve tartışmalar, Akademik incelemeler Dergisi, 13(1): 227-262.

T. C. Dışişleri Bakanlığı, BM İklim Değişikliği Çerçeve Sözleşmesi, http://www.mfa.gov.tr/bm-iklimdegisikligi-cerceve-sozlesmesi.tr.mfa (18.12.2020).

T. C. Enerji ve Tabii Kaynaklar Bakanlığı, 2019 Faaliyet Raporu, Strateji Geliştirme Başkanlığı, https://enerjiapi.etkb.gov.tr//Media/Dizin/SGB/Faaliyet_Raporlari/2019/ETKB\%202019\%20Y\%C4 \%B1|\%C4\%B1\%20Faaliyet\%20Raporu.pdf, (17.12.2020a) 
T. C. Enerji ve Tabii Kaynaklar Bakanlığı, İklim Değişikliği ve Uluslararası Müzakereler, https://enerji.gov.tr/bilgi-merkezi-iklim-degisikligi-ve-uluslararasi-muzakereler, (17.12.2020b).

Talu, N. (2015). Türkiye'de iklim değişikliği siyaseti, Ankara.

TEIAŞ, 2009 ve 2019 Yılları İçin Birincil Enerji Kaynaklarına Göre Türkiye Kurulu Gücü, https://webapi.teias.gov.tr/file/77439117-b6fa-465f-ab32-874c87ae456c?download

(17.12.2020a)

TEIAŞ, 2019 Yılı Türkiye Elektrik Enerjisi Üretiminin Kaynaklara Göre Dağılımı, https://webapi.teias.gov.tr/file/353c7742-77c6-426b-97fc-6220788257e6?download (17.12.2020c)

TEIAŞ, 2019 Yılı Türkiye Yenilenebilir Enerji Kaynakları Dağılımı, https://webapi.teias.gov.tr/file/7a0c321b-ec60- 411a-a54a-c8b44d06bcd0?download (17.12.2020b)

TÜRÇEV, Mavi Bayrak, http://www.mavibayrak.org.tr/tr/Default.aspx, (18.12.2020)

Yıldırım, H. H. (2019). Yenilenebilir enerji yatırımlarındaki teşviklerin yatırım performansları üzerine etkisi, Finans Ekonomi ve Sosyal Araştırmalar Dergisi, 4(3): 330-345.

Yıldız, Z. (2009). Küresel ısınma ve alternatif turizme yönelim üzerine etkileri, Süleyman Demirel Üniversitesi Vizyoner Dergisi, 1(1): 77-91.

Yılmazer, M., Çınar, S. (2017). Gelişmekte olan ülkelerde küresel ısınma ve sanayileşme olgusu: Brics ülkeleri ve Türkiye örneği, H. Atik (Ed.) Küresel ısınma, iklim değişikliği ve sosyo-ekonomik etkileri, (s. 38-59) içinde. Ankara. 